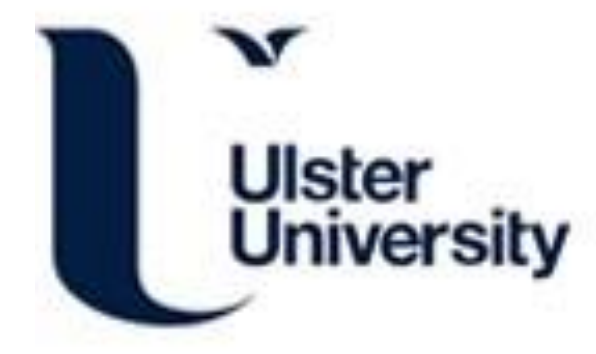

\title{
Gene Editing for Corneal Stromal Regeneration
}

Moore, T. C. B., Chao-Shern, C., DeDionisio, L., Christie, K. A., \& Nesbit, M. A. (2020). Gene Editing for Corneal Stromal Regeneration. In M. Ahearne (Ed.), Corneal Regeneration: Methods in Molecular Biology (Vol. 2145, pp. 59-75). (Methods in Molecular Biology; Vol. 2145). Springer Nature. https://doi.org/10.1007/978-1-0716-05998_6

Link to publication record in Ulster University Research Portal

\author{
Published in: \\ Corneal Regeneration
}

Publication Status:

Published online: 16/06/2020

DOI:

10.1007/978-1-0716-0599-8_6

\section{Document Version}

Author Accepted version

\section{General rights}

Copyright for the publications made accessible via Ulster University's Research Portal is retained by the author(s) and / or other copyright owners and it is a condition of accessing these publications that users recognise and abide by the legal requirements associated with these rights.

\section{Take down policy}

The Research Portal is Ulster University's institutional repository that provides access to Ulster's research outputs. Every effort has been made to ensure that content in the Research Portal does not infringe any person's rights, or applicable UK laws. If you discover content in the Research Portal that you believe breaches copyright or violates any law, please contact pure-support@ulster.ac.uk. 


\title{
Gene Editing for Corneal Stromal Regeneration
}

\author{
Tara Moore 1,2凹 \\ Email tara.moore@ulster.ac.uk \\ Connie Chao-Shern 1,2 \\ Larry DeDionisio 2
}

Kathleen A. Christie 1

M. Andrew Nesbit 1

1 Biomedical Sciences Research Institute, Ulster University, Coleraine, Northern Ireland, UK

2 Avellino Lab USA, Inc., Menlo Park, CA, USA

\section{Abstract}

CRISPR/Cas9 gene editing holds the promise of sequence-specific alteration of the genome to achieve therapeutic benefit in the treated tissue. Cas9 is an RNA-guided nuclease in which the sequence of the RNA can be altered to match the desired target. However, care must be taken in target choice and RNA guide design to ensure both maximum on-target and minimum off-target activity. The cornea is an ideal tissue for gene therapy due to its small surface area, accessibility, immune privilege, avascularity, and ease of visualization. Herein, we describe the design, testing, and delivery of Cas 9 and guide RNAs to target genes expressed in the cornea.

\section{Key words}

Gene editing

sgRNA expression construct

Dual luciferase assay

In vitreIn vitro digest

Lymphoblastoid cell line

Nucleofection

Polymerase chain reaction (PCR)

Corneal endothelial and epithelial cell culture

In viveIn vivo imaging

Intracameral injection

Adeno-associated virus (AAV)

\section{Introduction}

The discovery, development, and application of Clustered Regularly Interspaced Palindromic Repeats (CRISPR)/CRISPR associated protein (Cas) systems has brought the promise of gene therapy, tailored specifically for the patient, closer to realization. CRISPR/Cas9 is a bacterial RNA-guided endonuclease that has been modified for use in mammalian cells, consisting of a Cas9 nuclease that forms a complex with a simplified single guide RNA (sgRNA), formed by the fusion of crRNA and tracrRNAs, which guides the nuclease to its DNA target $[1,2,3]$. In addition to a match between the RNA and DNA sequences, the Cas9 nuclease itself recognizes and binds to a protospacer adjacent motif (PAM) directly upstream of the guide RNA sequence (Fig. 
1). Following target recognition, the Cas9 nuclease makes a double strand break (DSB) which triggers the DNA repair machinery of the cell, leading to either error-prone nonhomologous end joining (NHEJ) or precise homology directed repair (HDR) [4]. It is by harnessing these different cellular responses that different forms of gene editing can be achieved. It is important to understand, however, that DNA cleavage by Cas9 nuclease can occur in some cases where there are mismatches between the guide sequence and the target $[5,6]$. This can lead to off-targeting elsewhere in the genome or, as we have shown [7], failure to discriminate between mutant and wild-type alleles. Selectivity between wild-type and mutant alleles can be improved if the mutation is located within the PAM [7, 8, 9].

\section{Fig. 1}

S. pyogenes Cas9 (purple outline) can be directed to cut any sequence in the genome (DNA target in grey), provided it is directly upstream of a protospacer adjacent motif known as PAM (pink box). This can be achieved by altering the 20 nucleotide guide sequence, which is associated with a 82 nucleotide scaffold [8]
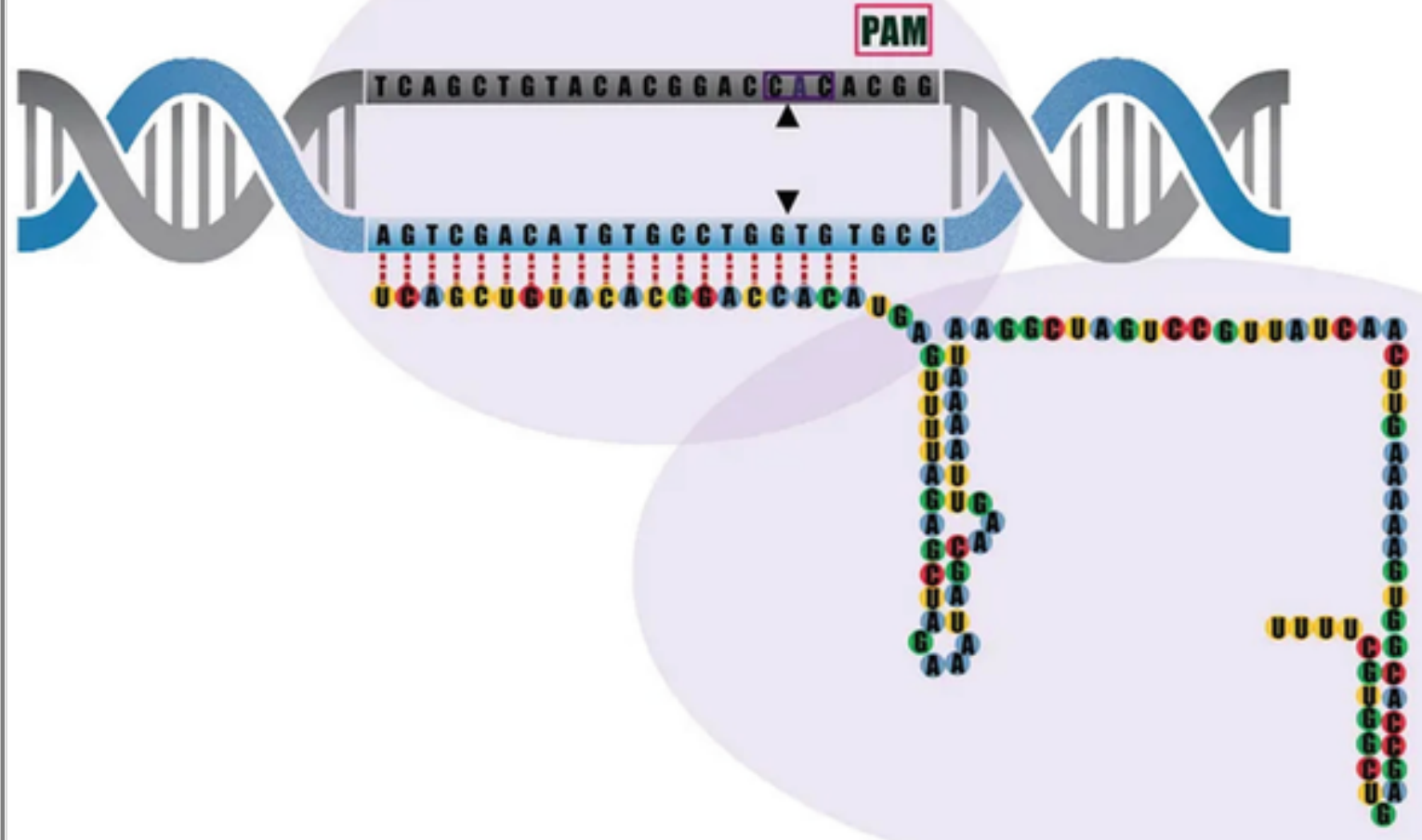

AQ1

Successful application of targeted CRISPR/Cas9 gene editing requires a stepwise approach by (1) careful selection of the target, (2) testing the efficiency with which the Cas9/sgRNA nuclease cleaves the selected target (on-target), (3) the specificity for the on-target compared to off-target, and (4) consideration of the method of delivery to the chosen tissue.

\section{Materials}

\subsection{SpCas9 sgRNA Design}

1. Sequence of target gene. 
2. Online design program (Benchling, CasOFFinder, etc.).

\section{2. sgRNA Construct Preparation}

1. S. pyogenes $S$. pyogenes Cas9 vector plasmid or S. aureus $S$. aureus Cas9 vector plasmid.

2. Bbsl This should be BbsI not Bbs1 restriction endonuclease.

3. Guide oligos containing the following template:

4. Top guide oligo-5'-CACCG - insert 20 nt of $\operatorname{sgRNA}-3^{\prime}$.

5. Bottom guide oligo-5'-C - insert complement of 20 nt CAAA - 3'.

6. T4 DNA ligase.

7. LB Broth.

8. LB Agar.

9. Antibiotic_check plasmid map to see which is needed.

10. dH5a E. coliE. coli competent cells.

11. Plasmid DNA isolation kit.

\subsection{Human Embryonic Kidney Cells (HEK) AD293 Maintenance}

1. HEK AD293 cells.

2. DMEM low glucose.

3. Fetal bovine serum.

4. Trypsin/EDTA $(0.25 \%)$.

5. Phosphate-buffered saline.

\subsection{Dual Luciferase Assay}

1. DMEM low glucose.

2. Fetal bovine serum.

3. S. pyogenesS. pyogenes Cas9 vector plasmid containing sgRNA of interest pSpCas9(BB)-2A-Puro (PX459) V2.0.

4. psiTEST-LUC-target vector containing target sequence of sgRNA. 
5. Renilla luciferase reporter plasmid.

6. Lipofectamine 2000 .

7. Optimem.

8. Dual-Luciferase ${ }^{\circledR}$ Reporter Assay System.

9. BMG Labtech, LUMIstar Optima plate reader (or equivalent).

\subsection{In VitreIn Vitro DNA Cleavage Assay}

1. S. pyogenes S. pyogenes EnGen Cas9 S.pyogenesS.pyogenes and reaction buffer.

2. Modified synthetic sgRNA.

3. Nuclease-free $\mathrm{H}_{2} \mathrm{O}$.

4. Proteinase $\mathrm{K}$.

5. DNA cleavage template containing $20 \mathrm{bp}$ target site and adjacent PAM (The cleavage template can either be circular or linearized plasmid, PCR products, or synthesized oligonucleotides).

\subsection{Generate Lymphocyte Cell Line (LCL)}

1. RPMI media.

2. Fetal bovine serum.

3. Ficoll-Paque PLUS.

4. Epstein-Barr virus (Human gammaherpesvirus 4 (HHV-4), ATCC® VR-1492).

5. Phytohemagglutinin.

\subsection{Nucleofection of LCLs with Ribonucleic Proteins (RNPs)}

1. S. pyogenes EnGen Cas9 NLS.

2. Modified synthetic sgRNA.

3. SF Cell line 4D-Nucleofector X kit.

4. Lonza 4D nucleofector.

5. QIAamp DNA Mini Kit. 


\subsection{Polymerase Chain Reaction (PCR)}

1. Dream Taq.

2. Primers flanking region of interest.

3. DNA to be amplified.

4. Thermocycler.

\subsection{Intrastromal Injection of CRISPR/Cas9}

1. Capillary Glass, $1.0 \mathrm{~mm}$ outer diameter, $0.58 \mathrm{~mm}$ inner diameter, $10.16 \mathrm{~cm}$ (4 in.).

2. DMZ universal puller (or equivalent).

3. Hamilton $701 \mathrm{RN} 10 \mu \mathrm{L}$ syringe without needle.SYR W/ONEEDLE.

4. Hamilton RN Compression Fitting $1 \mathrm{~mm}$.

5. Ketamine.

6. Xylazine.

7. $\mathrm{dH}_{2} \mathrm{O}$ for injections,

8. Tropicamide.

9. Phenylephrine.

10. Tooth (palate) bar only from model 923-B Mouse Gas Anesthesia Head Holder.

11. Gas mask.

12. Surgical microscope.

13. Fusidic gel.

AQ2

\subsection{IVIS In ViveIn Vivo Imaging of Fluorescence}

1. Isoflurane.

2. Isoflurane chamber.

3. Xenogen IVIS Lumina ivin vivo imager.

4. Custom mouse holder tube (Fig. 2). 
5. $1.5-2 \%$ isoflurane.

Fig. 2

Custom-made mouse holder for use in the IVIS that allows eyes to be placed at optimal angle to the camera

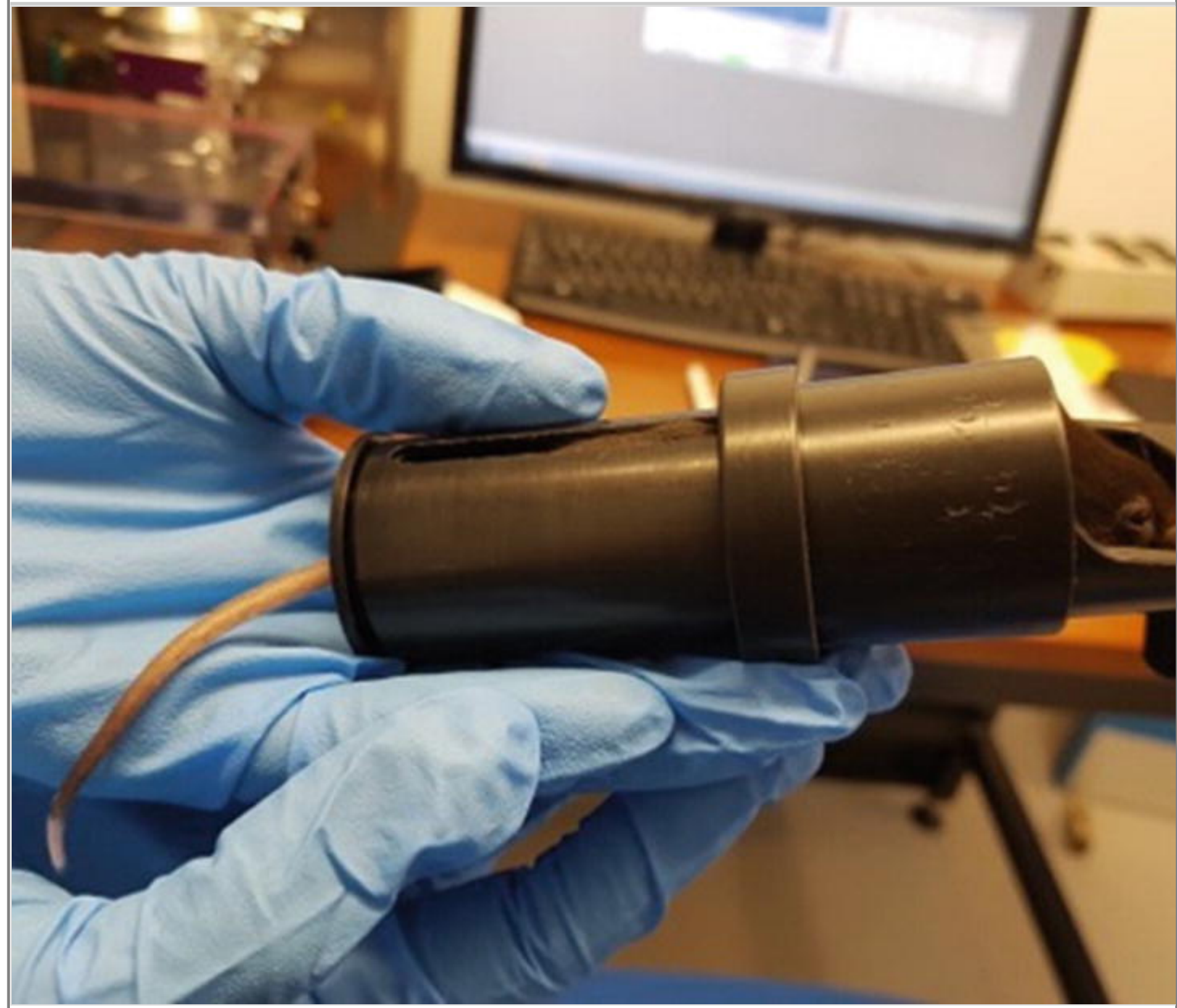

\section{Methods}

\section{1. sgRNA Design}

sgRNAs are designed using an online design program (Benchling, CasOFFinder, etc.) and chosen on the basis of good on- and off-target scores. Overhangs for the BbsI restriction site (shown in bold) are added to the $20 \mathrm{bp}$ sgRNA sequence of the target site. Top and bottom sgRNA oligos are ordered using the following template:

Top guide oligo-5'-CACCG insert 20 nt of sgRNA - 3' 
Bottom guide oligo - 5'-C insert complement of 20 nt CAAA - 3'

\subsection{CRISPR/Cas9 Construct Preparation}

1. Digest pSpCas9(BB)-2A-Puro (PX459) V2.0 with BbsI and Buffer 2.1 for 2 hours at $37{ }^{\circ} \mathrm{C}$ using the following reaction mixture:

\begin{tabular}{|l|l|}
\hline & \multicolumn{1}{|c|}{ Volume } \\
\hline $\mathrm{H}_{2} \mathrm{O}$ & Up to $50 \mu \mathrm{L}$ \\
\hline Buffer 2.1 (10×) & $5 \mu \mathrm{L}$ \\
\hline Plasmid DNA & $1 \mu \mathrm{g}$ \\
\hline BbsI restriction enzyme & $1 \mu \mathrm{L}$ \\
\hline
\end{tabular}

2. Digestion mix is then electrophoresed on a $1 \%$ agarose gel alongside a DNA ladder; linearized pSpCas9(BB)-2A-Puro (PX459) V2.0 plasmid will run at $9 \mathrm{~kb}$. Purify gel fragment containing your cloning backbone.

3. Resuspend the top and bottom strands of oligos for each guide oligo previously designed to a final concentration of $10 \mu \mathrm{M}$. Prepare the following mixture for annealing the sgRNA oligos (top and bottom strands):

\begin{tabular}{|l|l|}
\hline & Volume \\
\hline Top Oligo $(100 \mu \mathrm{M})$ & $1 \mu \mathrm{L}$ \\
\hline Bottom Oligo $(100 \mu \mathrm{M})$ & $1 \mu \mathrm{L}$ \\
\hline $\mathrm{H}_{2} \mathrm{O}$ & $7 \mu \mathrm{L}$ \\
\hline $5 \times$ DNA Ligase Buffer & $2 \mu \mathrm{L}$ \\
\hline
\end{tabular}

4. Anneal the oligos in a thermocycler by using the following parameters: $37^{\circ} \mathrm{C}$ for $30 \mathrm{~min} ; 95^{\circ} \mathrm{C}$ for $5 \mathrm{~min}$; ramp down to $25^{\circ} \mathrm{C}$ at $5^{\circ} \mathrm{C} / \mathrm{min}$.

5. Dilute the oligos ( $2 \mu \mathrm{L}$ annealed oligo: $98 \mu \mathrm{L}$ water $)$.

6. Set up a ligation reaction for each sgRNA, as described below. Include a no-insert, pSpCas9(BB)-only negative control for ligation.

\begin{tabular}{|l|l|}
\hline & Volume \\
\hline Digested $S p$ Cas9 Plasmid & $100 \mathrm{ng}$ \\
\hline Diluted annealed Oligos & $2 \mu \mathrm{L}$ \\
\hline $5 \times$ DNA Ligation Buffer & $4 \mu \mathrm{L}$ \\
\hline
\end{tabular}




\begin{tabular}{|l|l|}
\hline & Volume \\
\hline $\mathrm{H}_{2} \mathrm{O}$ & $\mathrm{X} \mu \mathrm{L}$ \\
\hline DNA Ligase Buffer & $1 \mu \mathrm{L}$ \\
\hline Total Reaction Volume & $20 \mu \mathrm{L}$ \\
\hline
\end{tabular}

7. Incubate the ligation mixture for 1 hour at room temperature.

8. Add $4 \mu \mathrm{L}$ ligation mixture to $45 \mu \mathrm{L}$ of competent E. coli $E$. coli strain e.g.dH5. DH5 $\alpha$ cells in a prechilled tube.

(a) Leave on ice for $30 \mathrm{~min}$.

(b) Heat shock for $45 \mathrm{~s}$ in a preheated water bath at $42{ }^{\circ} \mathrm{C}$.

(c) Leave on ice for $2 \mathrm{~min}$.

(d) Add $150 \mu \mathrm{L}$ of prewarmed LB broth to centrifuge tube.

(e) Incubate in shaking incubator at $37^{\circ} \mathrm{C}$ for 1 hour.

(f) Plate all $200 \mu \mathrm{L}$ transformation mix onto an LB agar plate containing $100 \mu \mathrm{g} / \mathrm{mL}$ ampicillin and place in $37^{\circ} \mathrm{C}$ incubator overnight.

9. Inspect the plates for colony growth. Pick colonies with a sterile tip and place into $20 \mu \mathrm{L}$ LB broth in a $0.5 \mathrm{~mL}$ tube, select $\sim 4$ colonies per plate. Shake tip in LB to dislodge bacteria, remove, and discard tip.

10. Vortex each tube briefly to disperse bacterial colony.

11. Perform colony PCR to determine successful ligation using the reaction below:

\begin{tabular}{|l|l|}
\hline \multicolumn{1}{|c|}{ Reagents } & $1 \times$ Reaction \\
\hline $5 \times$ Dream Taq Buffer & $4 \mu \mathrm{L}$ \\
\hline $\begin{array}{l}\text { Forward primer } 10 \mu \mathrm{M} \\
(\text { Cas9 BB seq Fwd-5-gggaaacgcctggtatcttt-3') }\end{array}$ & $1 \mu \mathrm{L}$ \\
\hline $\begin{array}{l}\text { Reverse primer } 10 \mu \mathrm{M} \\
\text { (Bottom guide oligo-custom for each sgRNA) }\end{array}$ & $1 \mu \mathrm{L}$ \\
\hline Colony broth & $2 \mu \mathrm{L}$ \\
\hline $\mathrm{H}_{2} \mathrm{O}$ & $11.92 \mu \mathrm{L}$ \\
\hline Dream Taq & $0.08 \mu \mathrm{L}$ \\
\hline Total reaction volume & $20 \mu \mathrm{L}$ \\
\hline
\end{tabular}


12. Run PCR program:

\begin{tabular}{|l|l|}
\hline Pre-PCR holding stage & $95^{\circ} \mathrm{C}$ for $3 \mathrm{~min}$ \\
\hline Cycling stage (35 cycles) & $95^{\circ} \mathrm{C}$ for $15 \mathrm{~s}$ \\
\hline & $60^{\circ} \mathrm{C}$ for $15 \mathrm{~s}$ \\
\hline Post-PCR holding stage & $72^{\circ} \mathrm{C}$ for $30 \mathrm{~s}$ \\
\hline
\end{tabular}

13. After PCR, run the material on $1 \%$ agarose $1 \times$ TBE gel.

14. If the sgRNA has been inserted, there should be a product size of $210 \mathrm{bp}$. The reverse primer used in the PCR reaction is the bottom guide oligo; $;$ se therefore, this The forward primer primes off of the pSpCas9(BB)-2A-Puro (PX459) V2.0 backbone. ThereforeConsequently, there should only be a product in cases where the $20 \mathrm{bp}$ sgRNA has been inserted into the digested plasmid.

15. Inoculate $3 \mathrm{~mL}$ LB broth with $100 \mu \mathrm{g} / \mathrm{mL}$ ampicillin with broth containing dispersed insert-positive colony in LB broth.

16. Incubate culture in a shaking incubator at $37^{\circ} \mathrm{C}$ overnight.

17. Isolate plasmid DNA from the cultures using a plasmid DNA purification kit, following the manufacturer's protocol.

\subsection{HEK AD293 Cell LINE MAINTENANCE}

1. AD293 cells are cultured in $1 \times$ DMEM (containing $1 \mathrm{~g} / \mathrm{L}$ glucose, $4.0 \mathrm{mM}$ L-Glutamine, $1.0 \mathrm{mM}$ Sodium Pyruvate) and $10 \%$ heat-inactivated fetal bovine serum (FBS) in an incubator at $37{ }^{\circ} \mathrm{C}$ with $5 \%$ $\mathrm{CO}_{2}$.

2. Subculture conditions: Split sub-confluent cultures (70-80\%) from 1:2 to 1:3, seeding at $1 \times 10^{6}$ cells $/ \mathrm{cm}^{2}$ in a $75 \mathrm{~cm}^{2}$ flask, using $1 \times$ trypsin.

3. Remove the growth medium by aspiration.

4. Wash cells once with $2 \mathrm{~mL}$ phosphate-buffered saline.

5. Trypsinize cells for $1-3 \mathrm{~min}$ in $1 \times \operatorname{trypsin} / \mathrm{EDTA}$ at $37^{\circ} \mathrm{C}$.

6. Dilute the cells with growth medium (volume at least equal to the volume of trypsin/EDTA solution added) to inactivate the trypsin.

7. Transfer cell suspension to a conical tube and centrifuge at $1000 \times g$ for 5 min at room temp.

8. Aspirate the supernatant and resuspend cells in $10 \mathrm{~mL}$ growth medium. 
9. Seed cells at appropriate cell density. Place the cells in a $37^{\circ} \mathrm{C}$ incubator at $5 \% \mathrm{CO}_{2}$. Monitor cell density daily.

\subsection{Preparation of psiTEST-LUC-target Vector}

1. Co-digest the psiTEST-LUC-target vector with NheI and KpnI in Buffer 1.1 for 2 hours at $37^{\circ} \mathrm{C}$. This plasmid will be used for both the dual-luciferase assay and the vitrein vitro digest reaction.

\begin{tabular}{|l|l|}
\hline & \multicolumn{1}{|c|}{ Volume } \\
\hline $\mathrm{H}_{2} \mathrm{O}$ & Up to $50 \mu \mathrm{L}$ \\
\hline Buffer 2.1 (10×) & $5 \mu \mathrm{L}$ \\
\hline Plasmid DNA & $1 \mu \mathrm{g}$ \\
\hline KpnI restriction enzyme & $1 \mu \mathrm{L}$ \\
\hline NheI restriction enzyme & $1 \mu \mathrm{L}$ \\
\hline
\end{tabular}

Digestion mix is then electrophoresed on a 1\% agarose gel alongside a DNA ladder; desired band will run at $5223 \mathrm{bp}$ and excised band will run at $12 \mathrm{bp}$. Purify gel fragment containing your cloning backbone.

2. Design a $50 \mathrm{bp}$ template containing your $20 \mathrm{bp}$ target sequence and adjacent PAM including overhangs complementary to the NheI and KpnI restriction sites.

3. Following steps 3-8 in Subheading 3.2 ligate the $50 \mathrm{bp}$ dsODN into the digested psiTEST-LUC-target vector.

4. Verify the $50 \mathrm{bp}$ dsODN has been inserted into the digested backbone using a colony PCR as previously described (Subheading 3.2, steps 9-13). Correct insertion will result in a PCR product of $641 \mathrm{bp}$; an empty backbone will result in a PCR product of $591 \mathrm{bp}$.

5. This construct can now be used directly in the dual-luciferase assay.

6. For the in vitrein vitro digest use the psiTEST-LUC-target vector containing the $50 \mathrm{bp}$ region encompassing your target site and adjacent PAM for PCR. Prepare PCR product containing the target sequence using the following primers:

(a) FWD: 5' - ACCCCAACATCTTCGACGCGGGC-3'

(b) REV: 5' - TGCTGTCCTGCCCCACCCCA - 3'

7. Purify PCR product and use in the vitrein vitro cleavage reaction at the specified concentration of $3 \mathrm{nM}$. The PCR product generated using the primers described in step 6 generates a template of $587 \mathrm{bp}$ which has a M.W of $356701.7 \mathrm{~g} / \mathrm{mol}$ (see Note 6) .

\subsection{Dual Luciferase Assay}


1. Dual Luciferase assay workflow (Fig. 3).

2. The day prior to transfection seed AD293 cells in a volume of $100 \mu \mathrm{L}$ in a 96 -well plate at a density of $6.5 \times 10^{3}$ cells per well.

3. Cells are transfected using Lipofectamine 2000 according to the manufacturers' instructions.

4. For each well the reaction mix is as follows:

\begin{tabular}{|l|l|}
\hline \multicolumn{1}{|c|}{ Reagents } & $\mathbf{1} \times$ reaction \\
\hline Firefly luciferase reporter plasmid & $20 \mathrm{ng}$ \\
\hline CRISPR/Cas9 expression construct & $80 \mathrm{ng}$ \\
\hline Renilla luciferase plasmid & $1 \mathrm{ng}$ \\
\hline Lipofectamine 2000 & $0.2 \mu \mathrm{L}$ \\
\hline Optimem & $25 \mu \mathrm{L}$ \\
\hline DMEM with $10 \%$ FBS & $25 \mu \mathrm{L}$ \\
\hline
\end{tabular}

5. Prepare a mastermix for you rexperimenta your experimental 1 design.

6. Combine Lipofectamine 2000 and Optimem and incubate at room temperature for 5 min.

7. Add Renilla plasmid.

8. Add Reporter construct plasmid.

9. Add sgRNA construct plasmid and incubate at room temperature for $5 \mathrm{~min}$.

10. Add DMEM with $10 \%$ FBS.

11. Remove $50 \mu \mathrm{L}$ culture medium from each well.

12. Add $50 \mu \mathrm{L}$ transfection mixture to each well.

13. Incubate for $72 \mathrm{~h} \mathrm{FBS} \mathrm{in} \mathrm{an} \mathrm{incubator} \mathrm{at} 37^{\circ} \mathrm{C}$ with $5 \% \mathrm{CO}_{2}$.

14. Prepare the lysates using the Dual-Luciferase ${ }^{\circledR}$ Reporter Assay System kit, following the manufacturer's instructions (seeNote 1).

\section{Fig. 3}

Explanation of dual-luc dual-luciferase assay. Diagram showing the different constructs that were transfected for the dual luciferase assay. The Renilla luciferase plasmid (Red) is used to normalize the firefly luciferase read, as it is not affected by the addition of sgGeneWT or sgGeneMut(ant). Firefly luciferase is shown in orange, while the sgRNAs for GeneWT and GeneMut(ant) are shown in green and blue, respectively [8] 
A

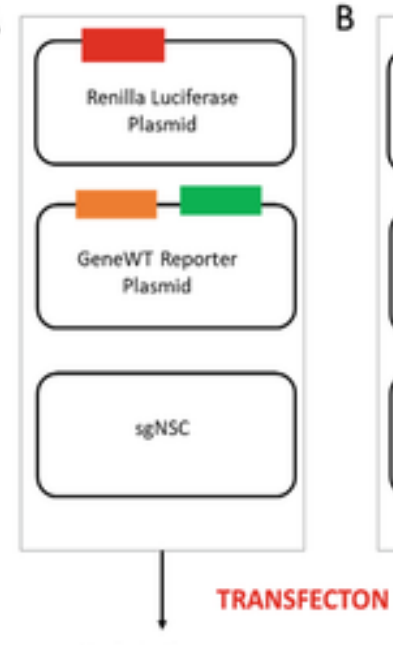

Firefly luciferase

level unaffected,

Renills luciferase

level remains

constant.

D

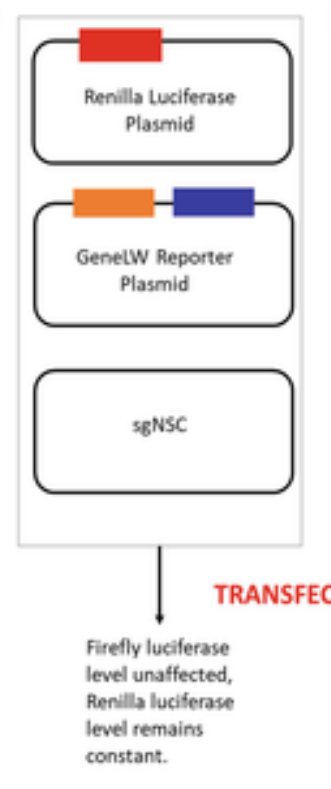

B

E

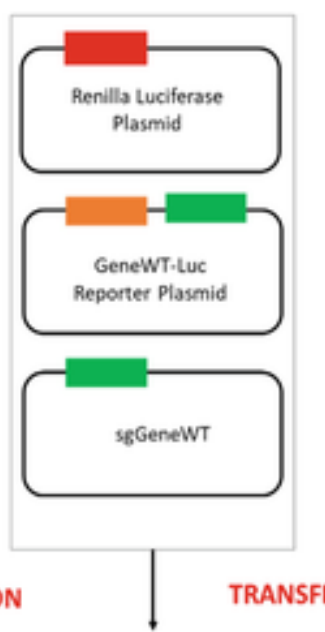

sgGeneWT targets the

GeneWT-Luc Reporter

Plasmid, see reduction

in firefly luciferase.

Renilla luciferase level

remains constant.
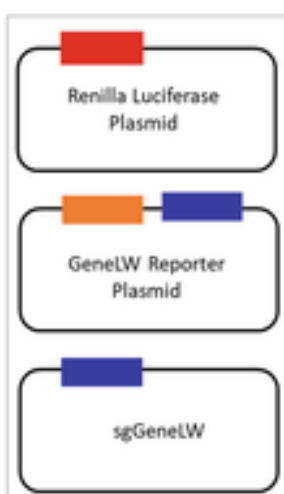

TRANSFECTON

sgGenelW targets the

GeneWT-Luc Reporter

Plasmid, see reduction

in firefly luciferase.

Renilla luciferase level

remains constant.
C

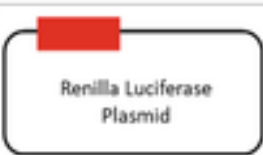

GenelW-Luc

Reporter Plasmid
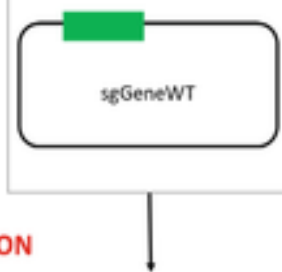

sgGeneWT targets the GenelW-Luc Reporter Plasmid as well, see reduction in firefly Iuciferase. Renillla luciferase level remains constant.

F

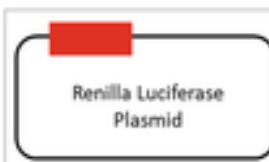

GenetW Reporte: Plasmid

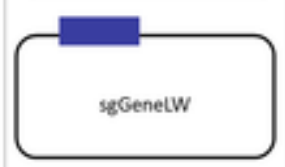

gGenelW does not target the GenelW-Luc Reporter Plasmid, see reduction in firefly luciferase. Renill, luciferase level remains constant.

\subsection{Post-transfection Luciferase Readout}

1. Perform post-transfection luciferase readout on the LUMIstar Optima microplate reader.

2. Aliquot the Dual-Luciferase ${ }^{\circledR}$ Reporter Assay System reagents prior the experiment into $15 \mathrm{~mL}$ centrifuge tubes and store at $-80^{\circ} \mathrm{C}$.

3. Defrost the LAR and Stop\&Glo reagents immediately before reading the plate (seeNote 2).

4. To prepare the Stop\&Glo reagent, dilute 50× Stop and Glo reagent (supplied with kit and kept at $-20^{\circ} \mathrm{C}$ ) with the $\mathrm{S} \& \mathrm{G}$ buffer previously aliquoted to make a $1 \times$ solution. 
5. In the LUMIstar Reagent Box, insert reagent injector 1 into the LAR solution and reagent injector 2 into the S\&G solution. Ensure each tube is inserted properly (seeNote 3).

6. Open the LUMIstar software.

7. Prime pumps (seeNote 4).

8. Click test protocols and select the pre-made program (seeNote 5).

9. Edit the layout, based on the experiment.

10. Press OK and click the measurement icon (Traffic lights icon).

11. When the plate run is complete, open the LUMIstar analysis software and select the plate run from the drop-down menu.

12. Save data as Excel spreadsheet for analyses.

13. After using the machine, wrap the remaining solutions in foil and store for future use.

14. Remove injector needles from holes in the bottom of the machine and place in a waste tube.

15. Place tubing 1 and 2 in a tube containing $\mathrm{dH}_{2} \mathrm{O}$, click the priming icon, and perform the first wash of machine using $\mathrm{dH}_{2} \mathrm{O}$.

16. Place tubing 1 and 2 in a tube containing isopropanol, click the priming icon, and perform the second wash of machine using isopropanol.

17. Finally, remove the tubing from isopropanol and prime pumps using air, ensuring that the needles are still in waste tube.

\subsection{In VitreIn Vitro DNA Cleavage Assay}

1. Prepare a cleavage template containing the target sgRNA sequence and an adjacent PAM. The cleavage template can either be circular or linearized plasmid, PCR products, or synthesized oligonucleotides (Subheading 3.4).

2. Prepare the reaction at room temperature in the following order:

\begin{tabular}{|l|l|}
\hline \multicolumn{1}{|c|}{ Reagents } & \multicolumn{1}{c|}{ Volume } \\
\hline $\mathrm{H}_{2} \mathrm{O}$ & $20 \mu \mathrm{L}$ \\
\hline $10 \times$ Cas9 Nuclease Reaction Buffer & $3 \mu \mathrm{L}$ \\
\hline $300 \mathrm{nM}$ sgRNA & $3 \mu \mathrm{L}(30 \mathrm{nM})$ \\
\hline $1 \mu \mathrm{M}$ Cas9 S. pyogenes & $1 \mu \mathrm{L}(30 \mathrm{nM})$ \\
\hline Reaction volume & $27 \mu \mathrm{L}$ \\
\hline
\end{tabular}


3. Pre-incubate for $10 \mathrm{~min}$ at $25^{\circ} \mathrm{C}$.

4. Add $3 \mu \mathrm{L} 30 \mathrm{nM}$ substrate DNA to the reaction ( $3 \mathrm{nM}$ final).

5. Incubate at $37^{\circ} \mathrm{C}$ for $15 \mathrm{~min}$.

6. Add $1 \mu \mathrm{L}$ of Proteinase $\mathrm{K}$ to each sample, mix thoroughly, and pulse-spin in a microfuge.

7. Incubate at room temperature for $10 \mathrm{~min}$.

8. Run digested products on a $1 \%$ agarose $1 \times$ TBEgel.

9. The fraction of the PCR product (587 bp) that is digested indicates the activity of the sgRNA.

10. An example of an in vitrøin vitro cleavage reaction output is shown below in Fig. 4.

Fig. 4

Confirmation of the specificity achieved using a guide-specific system targeted to prevalent FGFB $F T G F B I$ mutations. In vitreIn vitro digestion of either wild-type or respective mutant FGFB $I T G F B I$ sequence via Cas9 protein complexed with an sgRNA [8] 


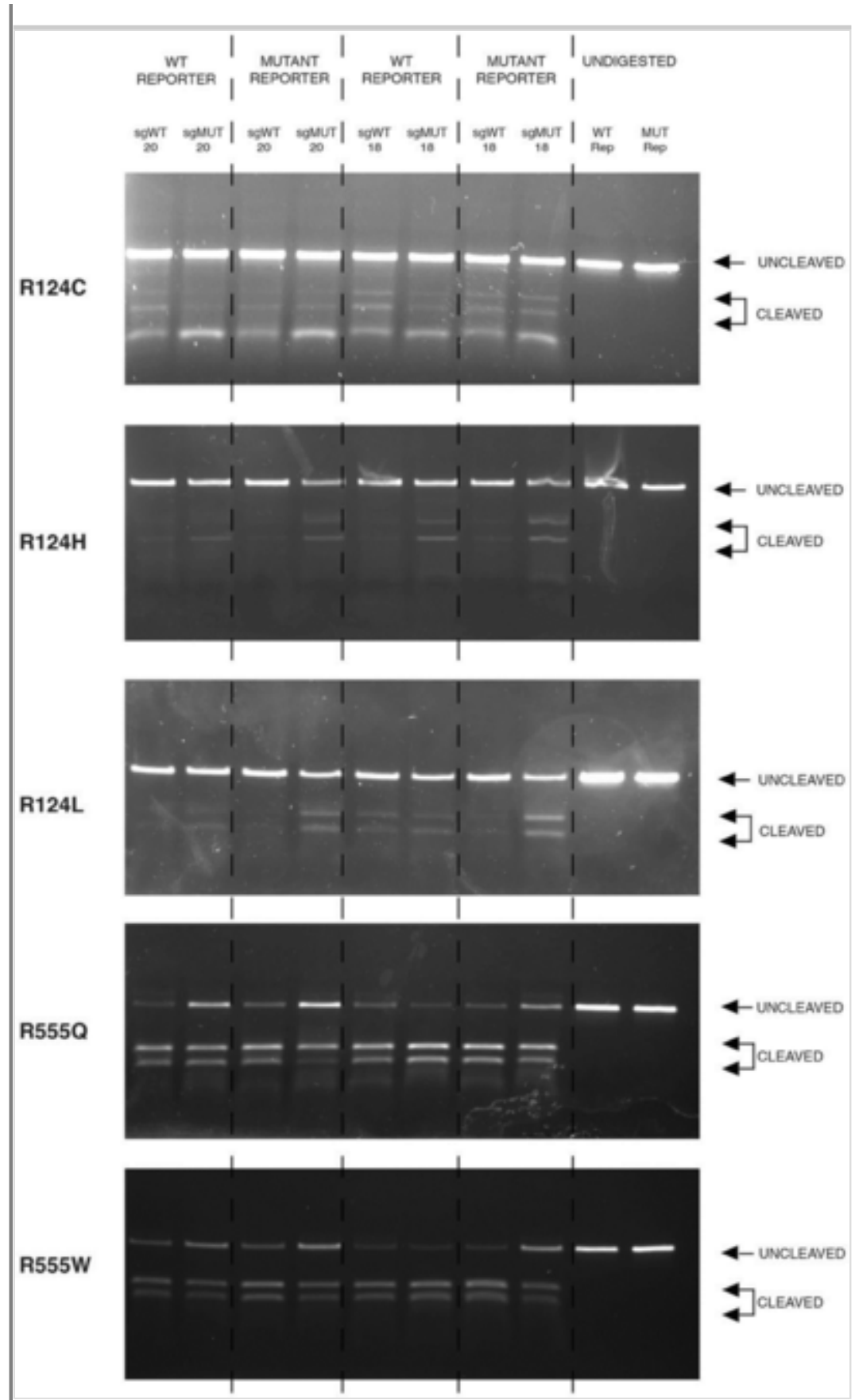

\subsection{Generate Patient-Derived Lymphoeyte Cell Line (LCL)}

1. Take $5 \mathrm{~mL}$ of freshly collected whole blood and place in a sterile $50 \mathrm{~mL}$ conical tube.

2. Add an equal volume of RPMI medium containing $20 \%$ fetal calf serum te and mix by gentle inversion. $\mathrm{AQ} 3$

3. Place $6.25 \mathrm{~mL}$ of Ficoll-Paque PLUS in a separate sterile $50 \mathrm{~mL}$ conical tube.

4. Very carefully add the $10 \mathrm{~mL}$ of blood/media mix to the Ficoll-Paque. Hold the tube with the FicollPaque at an angle of $45^{\circ}$ and then using a sterile $3 \mathrm{~mL}$ aspirating pipette (Pastette) gently run the blood down the side of the tube so that it forms a separate layer above the Ficoll-Paque (seeNote 7). 
5. Spin the tube at $400 \times g$ for $20 \mathrm{~min}$ at room temperature using slow acceleration and slow deceleration (brake off).

6. Remove the tube. The red blood cells will collect at the bottom of the tube above which will be the Ficoll-Paque layer. The lymphocytes should form a layer on top of the Ficoll-Paque layer, while the top layer will be the medium.

7. Insert a clean sterile Pastette to just above the Ficoll-Paque layer and draw off the lymphocytes, which are placed in a sterile $15 \mathrm{~mL}$ conical tube.

8. Centrifuge the lymphocytes at $60-100 \times g$ for $4 \mathrm{~min}$.

9. Carefully aspirate and discard the media.

10. Wash the pellet of lymphocytes with RPMI media (20\% FCS).

11. Centrifuge the lymphocytes at $60-100 \times g$ for $3 \mathrm{~min}$.

12. Aspirate and discard the majority of the media.

13. Resuspend the pelleted lymphocytes in the residual media.

14. Rapidly thaw an aliquot of EBV at $37^{\circ} \mathrm{C}$.

15. Add the thawed EBV suspension to the resuspended lymphocytes and mix gently.

16. Incubate for 1 hour at $37^{\circ} \mathrm{C}$ (infection period).

17. Add RPMI, 20\% FCS media to EBV-treated lymphocytes to give a total volume of $3 \mathrm{~mL}$.

18. Add $40 \mu \mathrm{L}$ of $1 \mathrm{mg} / \mathrm{mL}$ phytohemagglutinin and mix gently.

19. Aliquot $1.5 \mathrm{~mL}$ of the lymphocyte mixture to 2 of the middle wells of a 24 -well plate.

20. Add PBS to the surrounding wells of the plate to maintain humidity.

21. Incubate for 24 hours at $37^{\circ} \mathrm{C}$ with $5 \% \mathrm{CO}_{2}$ in tissue culture incubator.

22. After 24 hours, the lymphoblastoid cells should be observed to be aggregating.

23. When the media begins to turn yellow, replace with fresh media and expand cells as appropriate into 6well plates and small flasks.

24. Once in flasks, the serum content of the media can be reduced to $10 \%$.

\subsection{Nucleofection of LCLs with RNPs}

1. Ribenteleoprotein complexes (RNPs) are formed directly in the Lonza Nucleofector SF solution (SF Cell line 4D-Nucleofector X kit), and incubated for $10 \mathrm{~min}$ at room temperature. 
2. Prepare the reagents according to the following order:

\begin{tabular}{|l|l|}
\hline \multicolumn{1}{|c|}{ Reagent } & Volume \\
\hline Synthego modified sgRNA (30 pmol) & $2.66 \mu \mathrm{L}$ \\
\hline NEB EnGen SpCas9 (20 pmol) & $2 \mu \mathrm{L}$ \\
\hline Lonza Nucleofector SF solution & $20.34 \mu \mathrm{L}$ \\
\hline Total Volume & $25 \mu \mathrm{L}$ \\
\hline
\end{tabular}

3. Using a hemocytometer calculate the number of cells required per transfection and total number of cells required for the experiment.

4. Collect the total number of cells by centrifugation $(300 \times g \times 5 \mathrm{~min})$ and resuspend in Nucleofector solution by gently pipetting $(5 \mu \mathrm{L} /$ per reaction $)$.

5. $5 \mu \mathrm{L}$ of each cell solution was added to $25 \mu \mathrm{L}$ of corresponding preformed RNPs, mixed and transferred to the nucleofector 16-well strip.

6. The cells were electroporated using the 4D Nucleofector program DN-100, $70 \mu \mathrm{L}$ of pre-warmed media was added to each well and allowed to recover at room temperature for $5 \mathrm{~min}$.

7. The transfected cells were then transferred to a 24-well plate containing $200 \mu \mathrm{L}$ medium per well.

8. Incubate cells at $37^{\circ} \mathrm{C}$ for 48 hours.

9. 48 hours post nucleofection, extract gDNA from cells using the QIAamp DNA Mini Kit following the manufacturer's instructions.

\subsection{PCR for Tracking of Indels by Decomposition (TIDE)}

1. Design primers flanking the target site. Primers should generate a $\sim 700 \mathrm{bp}$ product, the target site should be $\sim 200 \mathrm{bp}$ from the sequencing start site.

2. Perform a gradient PCR to determine the annealing temperature.

3. Set up a PCR reaction as follows, include a non-edited control:

\begin{tabular}{|l|l|}
\hline \multicolumn{1}{|c|}{ Reagents } & \multicolumn{1}{c|}{$1 \times$ Reaction } \\
\hline $5 \times$ Dream Taq Buffer & $4 \mu \mathrm{L}$ \\
\hline Forward primer $10 \mu \mathrm{M}$ & $1 \mu \mathrm{L}$ \\
\hline Reverse primer $10 \mu \mathrm{M}$ & $1 \mu \mathrm{L}$ \\
\hline DNA template & $\begin{array}{l}\text { Plasmid DNA }=1 \text { pg to } 1 \mathrm{ng}, \\
\text { Human DNA }=50-100 \mathrm{ng}\end{array}$ \\
\hline
\end{tabular}




\begin{tabular}{|l|l|}
\hline \multicolumn{1}{|c|}{ Reagents } & \multicolumn{1}{c|}{$\mathbf{1 \times \text { Reaction }}$} \\
\hline $\mathrm{H}_{2} \mathrm{O}$ & Make up $20 \mu \mathrm{L}$ \\
\hline Dream Taq & $0.08 \mu \mathrm{L}$ \\
\hline
\end{tabular}

4. Electrophorese PCR products on a 1\% agarose gel alongside a DNA ladder to confirm the PCR reaction has produced a specific band at the expected size.

5. Purify the PCR product and send test and control PCR products for sanger Sanger sequencing.

6. Upload the sanger Sanger traces to the TIDE online program to quantify indels in your test sample. AQ4

\subsection{Intrastromal Injection of CRISPR/Cas9 Constructs}

1. Glass needles are prepared by pulling glass capillaries using program 17 on a DMZ Universal Puller.

2. Glass needles are fitted onto a Hamilton $10 \mu \mathrm{L}$ syringe using a compression fitting.

3. Anesthetize animals by an intra-peritoneal injection of ketamine and xylazine.

4. Position mouse on custom mouse tooth holder under the surgical microscope. Rotate the head of the mouse to have a bird's-eye view of the cornea.

5. Dilate pupils by topically applying one drop of tropicamide and phenylephrine on each eye.

6. $2 \mu \mathrm{g}$ of CRISPR/Cas9 expression construct is back-filled into a glass needle $(1.0 \mathrm{~mm})$ attached to a Hamilton $10 \mu \mathrm{L}$ syringe.

7. The glass needle is used to make a track in the stroma just above the periphery of the cornea, when the needle feels secure in the stroma inject the CRISPR/Cas9 expression construct.

8. Fusidic gel was applied topically following injection as an antibiotic agent.

\subsection{IVIS In ViveIn Vivo Imaging of Fluorescence in Mouse Eyes}

1. Anesthetize mice using $1.5-2 \%$ isoflurane in $\sim 1.5 \mathrm{~L} / \mathrm{min}$ flow of oxygen (setting 2.5 on isoflurane control).

2. Mice are placed in a custom mouse holder tube (Fig. 2) and placed inside a Xenogen IVIS Lumina in vivo imager.

3. A custom program to detect fluorescence or luminescence is selected and the signal is quantified.

\section{Notes}


1. Remove media from wells and wash with $100 \mu \mathrm{L}$ PBS. Then add $20 \mu \mathrm{L} 1 \times$ Passive Lysis buffer to each well, shake gently for 15 min on a plate shaker. Finally insert into the LUMIstar Optima plate reader.

2. Cover the $15 \mathrm{~mL}$ tubes completely in tin foil as reagents are light sensitive. Put the reagents in the LUMIstar compartment and close lid.

3. Care needs to be taken to prevent tube mix up.

4. Pump priming icon is on the top row of buttons in the LUMIstar software.

5. Use Greiner 96 F-bottom black wall microplate with 36 intervals, reading direction $\downarrow$. Volume for each injection is $36 \mu \mathrm{L}$.

6. Template $=587 \mathrm{bp}-\mathrm{M} . \mathrm{W}$ of $356701.7 \mathrm{~g} / \mathrm{mol}$, require $3 \mathrm{nM}$.

7. Avoid excessive mixing of the blood into the Ficoll-Paque layer.

8. Flasks must be coated with $10 \mu \mathrm{g} / \mathrm{mL}$ laminin and $10 \mathrm{mg} / \mathrm{mL}$ chondroitin sulfate (acts like the Descemet's membrane).

\section{References}

1. Jinek M, Chylinski K, Fonfara I, Hauer M, Doudna JA, Charpentier E (2012) A programmable dual-rnaguided DNA endonuclease in adaptive bacterial immunity. Science (New York, NY) 337(6096):816-821. http s://doi.org/10.1126/science.1225829

2. Mali P, Yang L, Esvelt KM, Aach J, Guell M, DiCarlo JE, Norville JE, Church GM (2013) Rna-guided human genome engineering via cas9. Science (New York, NY) 339(6121):823-826. https://doi.org/10.1126/science.1 232033

3. Cong L, Ran FA, Cox D, Lin S, Barretto R, Habib N, Hsu PD, Wu X, Jiang W, Marraffini LA, Zhang F (2013) Multiplex genome engineering using crispr/cas systems. Science (New York, NY) 339(6121):819-823. https://doi.org/10.1126/science.1231143

4. Ran FA, Hsu PD, Wright J, Agarwala V, Scott DA, Zhang F (2013) Genome engineering using the crispr-cas9 system. Nat Protoc 8(11):2281-2308. https://doi.org/10.1038/nprot.2013.143

5. Hsu PD, Scott DA, Weinstein JA, Ran FA, Konermann S, Agarwala V, Li Y, Fine EJ, Wu X, Shalem O, Cradick TJ, Marraffini LA, Bao G, Zhang F (2013) DNA targeting specificity of rna-guided cas9 nucleases. Nat Biotechnol 31(9):827-832. https://doi.org/10.1038/nbt.2647

6. Fu Y, Foden JA, Khayter C, Maeder ML, Reyon D, Joung JK, Sander JD (2013) High-frequency off-target mutagenesis induced by crispr-cas nucleases in human cells. Nat Biotechnol 31(9):822-826. https://doi.org/1 $0.1038 /$ nbt.2623

7. Moore CBT, Christie KA, Marshall J, Nesbit MA (2018) Personalised genome editing - the future for corneal dystrophies. Prog Retin Eye Res 65:147-165. https://doi.org/10.1016/j.preteyeres.2018.01.004

8. Christie KA, Courtney DG, DeDionisio LA, Shern CC, De Majumdar S, Mairs LC, Nesbit MA, Moore CBT (2017) Towards personalised allele-specific crispr gene editing to treat autosomal dominant disorders. Sci Rep 
7(1):16174. https://doi.org/10.1038/s41598-017-16279-4

9. Courtney DG, Moore JE, Atkinson SD, Maurizi E, Allen EH, Pedrioli DM, McLean WH, Nesbit MA, Moore CB (2016) Crispr/cas9 DNA cleavage at snp-derived pam enables both in vitro and in vivo krt12 mutationspecific targeting. Gene Ther 23(1):108-112. https://doi.org/10.1038/gt.2015.82 